М.В. ЯНЧИК, В.В. КІЙКО, Е.Ф. ХАЛІКОВА Національний університет харчових технологій

\title{
ВПЛИВ СОЄВОГО ЛЕЦИТИНУ НА ПОКАЗНИКИ ЯКОСТІ ГІРЧИЧНОГО ХЛІБА
}

\author{
М.В. ЯНЧИК, В.В. КИЙКО, Э.Ф. ХАЛИКОВА
}

Национальный університет пищевых технологий

\section{ВЛИЯНИЕ СОЕВОГО ЛЕЦИТИНА НА ПОКАЗАТЕЛИ КАЧЕСТВА ГОРЧИЧНОГО ХЛЕБА}

\author{
M.V. IANCHYK, V.V. KIIKO, E.F. KHALIKOVA \\ National University of Food Technology
}

\section{EFFECT OF SOYBEAN LECITHIN ON MUSTARD BREAD QUALITY INDICATORS}

\section{https://doi.org/10.36910/6775-2310-5283-2020-13-05}

Мета. Удосконаленя рецептури хліба гірчичного з використанням соєвого лецитину та визначення впливу обраної добавки на показники якості готового продукту впродовж зберігання

Методика. Для дослідження показників якості хліба гірчичного використовували загальноприйняті методики визначення органолептичних показників, вологості, кислотності, пористості, підйомної сили.

Результати. Удосконалено рецептуру хліба гірчичного з додаванням соєвого лециттну, обгрунтовано технологічну схему його виробництва та підібрано оптимальне дозування добавки. За результатами органолептичних досліджень та підйомної сили обрано дозування соєвого лецетину у кількості 0,6\%.

Досліджено органолептичні та фізико-хімічні показники хліба гірчичного 3 додаванням соєвого лецитину та без його використання. Виявлено, щзо зразок гірчичного хліба з додаванням соєвого лечитину характеризується більш гладенькою поверхнею, без тріщин та м'якушкою з рівномірно розподіленими порами, щуо гарно розжовується порівняно із контрольним зразком. Доведено, що в зразку гірчичного хліба з додаванням соєвого лециитину впродовж зберігання волога утримується набагато краще, спостерігається незначна зміна кислотності впродовж зберігання, а показник пористості є вищим як у свіжевиготовленого зразка так і після зберігання. 
Наукова новизна. Вперше удосконалено рецептуру гірчичного хліба за рахунок, додавання соєвого лецитину та досліджено його показники якості.

Практична значимість.Результати, які були отримані в ході досліджень, можна впровадити на хлібопекарських підприємствах України незалежно від форм власності та підпорядкування

Ключові слова: гірчичний хліб, соєвий лециттин, показники якості

Постановка проблеми у загальному вигляді і її зв'язок 3 важливими науковими та практичними завданнями. У хлібопекарській промисловості черствіння $\epsilon$ однією 3 головних проблем, 3 якою пов'язано зниження споживних властивостей хлібобулочних виробів, а також додаткові затрати на перероблення черствого хліба. В процесі зберігання хліба відмічається зниження показників якості: він втрачає свою м'якість, стає крихкуватим, зменшується його еластичність, втрачається смак і аромат, що пов'язане 3 процесом черствіння та усихання. Зміни властивостей хліба під час зберігання обумовлені складними фізико-хімічними, колоїдними та біохімічними процесами, що відбуваються в хлібі та втратою вологи.

Важливу роль відіграє старіння денатурованої у процесі випікання клейковини, яка віддає вологу i як наслідок поступово втрачає свою гідратаційну здатність, що призводить до ущільнення структури м'якушки. Тому наразі є актуальною проблемою подовження свіжості хліба, оскільки термін його зберігання є досить обмежений

Аналіз останніх досліджень, у яких започатковано вирішення проблеми. $B$ сучасному світі використовується різноманітна кількість добавок в хлібопекарському виробництві з метою поліпшення даного виду продукту.

Так, наприклад 3 метою сповільнення процесу черствіння хліба можна використовувати під час його виробництва добавки, які мають вплив на підвищення гідрофільних властивостей хліба. До них можна віднести солодові i ферментні препарати, мальтозні сиропи, а також препарати клейстеризованого крохмалю.

Ферментні препарати, виділені 3 культур плісеневих грибів, використовуютьдля пришвидшення процесу на етапі бродіння тіста i покращення якості хліба. Застосування ферментів дає змогу цілеспрямовано впливати на біополімерно-ферментативні комплекси борошна та змінювати його хлібопекарні властивості, і тим самим впливати на хід технологічного процесу. Найбільш ефективно уповільнюють процес черствіння хліба ферментні препарати, які продукують бактеріï Bacillus subtilis. Однак, відносно висока термостабільність бактеріальної амілази поряд з перевагами 
має і недоліки - перевищення оптимальної дози спричиняє липкість м’якушки хліба [1].

3 практики хлібопечення відомо, що деякі прості вуглеводи здатні уповільнювати черствіння виробів. Науковцями Національного університету харчових технологій (НУХТ) було проведено дослідження щодо впливу на процес черствіння заміни цукру на глюкозно-фруктозний сироп та мальтозну патоку. Ці цукрозамінники мають відмінний від сахарози вуглеводний склад, який відіграє важливу роль у формуванні структурно-механічних властивостей м'якушки та вподальшому впливаєна збереження виробами свіжості [2].

Відомо, що морські водорості у своєму складі мають гідрофільні складові, які здатні утримувати вологу. Так, у НУХТ досліджували вплив порошків морських водоростей на процеси черствіння хліба. Ступінь свіжості хліба оцінювали через 24, 48 год після випікання за зміною структурно-механічних властивостей м'якушки. Під час випікання хліба білки денатурують та виділяють вологу, зв’язуються крохмалем борошна та полісахаридами водоростей: ламінараном, фукоїданом, манітом. 3 підвищенням температури крохмаль клейстеризується, а полісахариди максимально набухають і утворюють більш еластичну м'якушку хліба. Під час зберігання хліба процес черствіння у дослідних зразках із водоростями уповільнюється на $3,2 \ldots 5 \%$ за рахунок вологоутримуючої здатності полісахаридів водоростей та зниження ступеня ретроградації крохмалю [3].

Перспективноюдобавкою для хлібобулочних виробів 3 метою підвищення харчової цінності $\epsilon$ овочеві порошки, які за оптимального дозування мають позитивний вплив на перебіг технологічного процесу, підвищують якість виробів, подовжують тривалість зберігання ними свіжості.

На цей час інститутом теоретичної теплофізики України одержані каротиновмісні порошки - гарбузовий та соєво-морквяний. Ці порошки багаті на харчові волокна, пектинові речовини, цукри, що свідчить про їх потенційну здатність затримувати черствіння хлібобулочних виробів.

Наприклад при зберігання виробів, що містять гарбузовий та соєвоморквяний порошки, структурно-механічні властивості м'якушки змінюються повільніше, ніж у зразках без додавання порошків. Це може відбуватись за рахуноксповільненням процесу ретроградації крохмалю внаслідок здатності пектинових речовин порошків утворювати білково-полісахаридні комплекси, що затримують його ретроградацію, а також сорбційними властивостями i підвищеною здатністю харчових волокон і пектинів зв’ язувати воду [4]. 
Цілі статті. Основною метою дослідження $є$ використання соєвого лецитину в технології гірчичного хліба та визначення його впливу на показники якості готового продукту. Для досягнення мети були поставлені наступні завдання:

- провести аналітичний огляд науково-технічної літератури;

- охарактеризувати об'єкти та методи дослідження;

- удосконалити та обгрунтувати рецептуру гірчичного хлібу з додаванням соєвого лецитину;

- дослідити показники якості гірчичного хліба 3 додаванням соєвого лецитину впродовж зберігання.

Об’єкт дослідження. Об'єктом дослідження $є$ рецептура хліба гірчичного з соєвим лецитином. Предметом дослідження є соєвий лецитин, гірчичний хліб із додаванням соєвого лецитину.

Методи дослідження.Органолептичні методи дослідження використовували для визначення форми хліба, його кольору, стану поверхні та м'якушки, характеру пористості, смаку, запаху, свіжості. Вони базуються на визначенні показників якості хліба гірчичного на основі аналізу сприйняття органів чуття. Органолептичні дослідження проводили згідно ДСТУ-П 8536:2015 «Вироби хлібобулочні. Органолептичне оцінювання показників якості» та ДСТУ 7044:2009 «Вироби хлібобулочні. Правила приймання, методи відбирання проб, методи визначення органолептичних показників і маси виробів». Результати порівнювали з вимогами, які зазначені у ДСТУ 7517:2014 «Хліб із пшеничного борошна. Технічні умови» [5].

Фізико-хімічними методами визначали вологість, кислотність, пористість хліба.Визначення пористості м'якушки гірчичного хліба з додаванням соєвого лецитину проводилось методом визначення маси та об'єму виїмки, за допомогою приладу Журавльова згідно вимог ДСТУ 7045:2009 «Вироби хлібобулочні. Методи визначання фізико-хімічних показників» [6].

Визначення вологості м'якушки гірчичного хліба проводилось методом висушування в сушильній шафі СЕШ-3М за ДСТУ 7045:2009 «Вироби хлібобулочні. Методи визначання фізико-хімічних показників» [7].

Визначення кислотності м'якушки гірчичного хліба проводилось арбітражним методом (титруванням гідроксидом натрію) за ДСТУ 7045:2009 «Вироби хлібобулочні. Методи визначання фізико-хімічних показників». Визначення підйомної сили здійснювали прискореним методом - по кульці тіста. За часом спливання кульки тіста характеризують підйомну силу. Підйомна сила - це здатність дріжджів засвоювати вуглеводи борошна. 


\section{Виклад основного матеріалу дослідження 3 повним обгрунтуванням} отриманих наукових результатів. 3 літературних джерел відомо, що емульгатори покращують структуру пористості хлібобулочних виробів, збільшують питомий об'єм і подовжують тривалість зберігання. Одним із натуральних емульгаторів $\epsilon$ соєвий лецитин, тому доцільному було дослідити його оптимальне дозування до рецептурної маси гірчичного хліба. Лецитин дозували в кількості 0,$5 ; 0,6 ; 0,7$ \% до маси борошна. Характеристика органолептичних властивостей представлена в таблиці 1.

Таблиця 1

\section{Характеристика органолептичних показників гірчичного хліба 3 різним дозуванням сосвого лецитину}

\begin{tabular}{|c|c|c|c|c|}
\hline \multirow{2}{*}{$\begin{array}{c}\text { Показник } \\
\text { якості хліба }\end{array}$} & \multirow{2}{*}{$\begin{array}{c}\text { Контроль, без } \\
\text { добавок }\end{array}$} & \multicolumn{3}{|c|}{ Дозування соєвого лецитину, \% до маси борошна } \\
\hline & & 0,5 & 0,6 & 0,7 \\
\hline $\begin{array}{l}\text { Правильність } \\
\text { форми }\end{array}$ & $\begin{array}{c}\text { Хліб із ледве } \\
\text { опуклою } \\
\text { верхньою } \\
\text { скоринкою }\end{array}$ & $\begin{array}{c}\text { Хліб із } \\
\text { випуклою } \\
\text { верхньою } \\
\text { скоринкою }\end{array}$ & $\begin{array}{c}\text { Хліб із помітно } \\
\text { випуклою } \\
\text { верхньою } \\
\text { скоринкою }\end{array}$ & $\begin{array}{c}\text { Хліб із помітно } \\
\text { випуклою } \\
\text { верхньою } \\
\text { скоринкою }\end{array}$ \\
\hline Колір скоринки & Золотистий & Золотистий & Золотистий & Золотистий \\
\hline $\begin{array}{l}\text { Стан поверхні } \\
\text { скоринки }\end{array}$ & $\begin{array}{c}\text { Гладенька, } \\
\text { одиничні } \\
\text { пухирці, } \\
\text { помітні } \\
\text { тріщини }\end{array}$ & $\begin{array}{c}\text { Гладенька, без } \\
\text { підривів, } \\
\text { глянцева, } \\
\text { помітні } \\
\text { тріщини }\end{array}$ & $\begin{array}{c}\text { Бездоганно } \\
\text { гладенька, без } \\
\text { пухирців, } \\
\text { глянцева }\end{array}$ & $\begin{array}{c}\text { Бездоганно } \\
\text { гладенька, без } \\
\text { пухирців глянцева }\end{array}$ \\
\hline $\begin{array}{l}\text { Колір } \\
\text { м'якушки }\end{array}$ & Світлий & Світлий & Світлий & Світлий \\
\hline $\begin{array}{l}\text { Структура } \\
\text { пористості }\end{array}$ & $\begin{array}{l}\text { Пори дрібні } \\
\text { та середні, } \\
\text { розподілені } \\
\text { досить } \\
\text { рівномірно }\end{array}$ & $\begin{array}{l}\text { Пори дрібні та } \\
\text { середні, } \\
\text { розподілені } \\
\text { досить } \\
\text { рівномірно }\end{array}$ & $\begin{array}{c}\text { Пори дрібні та } \\
\text { середні, } \\
\text { розподілені } \\
\text { досить } \\
\text { рівномірно }\end{array}$ & $\begin{array}{l}\text { Пори дрібні, } \\
\text { тонкостінні, } \\
\text { нерівномірно } \\
\text { розподілені }\end{array}$ \\
\hline $\begin{array}{l}\text { Смак та аромат } \\
\text { хліба }\end{array}$ & $\begin{array}{c}\text { Інтенсивно } \\
\text { виражений, } \\
\text { характерний } \\
\text { хлібний }\end{array}$ & $\begin{array}{c}\text { Інтенсивно } \\
\text { виражений, } \\
\text { властивий для } \\
\text { хліба }\end{array}$ & $\begin{array}{c}\text { Інтенсивно } \\
\text { виражений, } \\
\text { властивий для } \\
\text { хліба }\end{array}$ & $\begin{array}{c}\text { Інтенсивно } \\
\text { виражений, } \\
\text { властивий для } \\
\text { хліба }\end{array}$ \\
\hline $\begin{array}{l}\text { Розжовуваність } \\
\text { м’якушки }\end{array}$ & $\begin{array}{c}\text { Досить ніжна, } \\
\text { ледь сухувата, } \\
\text { добре } \\
\text { розжовується }\end{array}$ & $\begin{array}{c}\text { Дуже ніжна, } \\
\text { соковита, } \\
\text { добре } \\
\text { розжовується }\end{array}$ & $\begin{array}{c}\text { Дуже ніжна, } \\
\text { соковита, гарно } \\
\text { розжовується }\end{array}$ & $\begin{array}{c}\text { Дуже ніжна, } \\
\text { соковита, добре } \\
\text { розжовується }\end{array}$ \\
\hline
\end{tabular}


3 метою визначення оптимального дозування соєвого лецитину розроблено балову шкалу та проведено оцінку органолептичних показників якості зразків гірчичного хліба з різним дозуванням лецитину (рис. 1).

3 рисунку видно, що найкращі органолептичні показники гірчичного хлібу властиві зразку з додаванням соєвого лецитину 0,6\% до маси борошна. Серед усіх зразків в ньому переважає структура пористості та розжовуваність м'якушки [10].

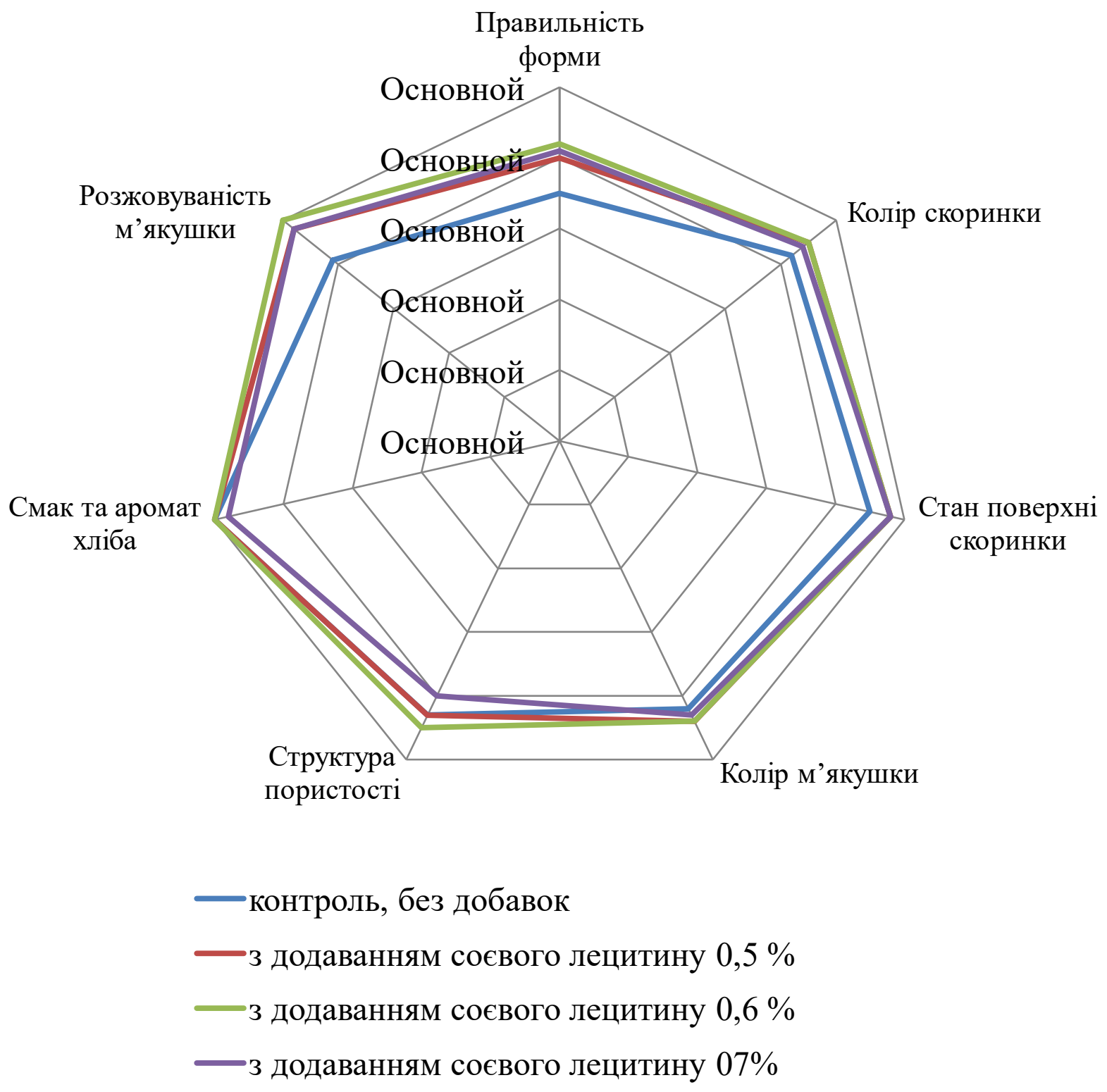

Рис.1. Балова оцінка органолептичних показників якості зразків гірчичного хліба з різним дозуванням соєвого лецитину до маси борошна

Одним 3 найважливіших показників для хлібобулочних виробів $\epsilon$ підйомна сила, що характеризує здатність дріжджів засвоювати вуглеводи 
борошна. Даний показник в подальшому впливає на органолептичні властивості, в тому числі важливу роль відіграє при утворенні пористої структури. Тому проведено дослідження підйомної сили з різним дозування соєвого лецитину (рис. 2).

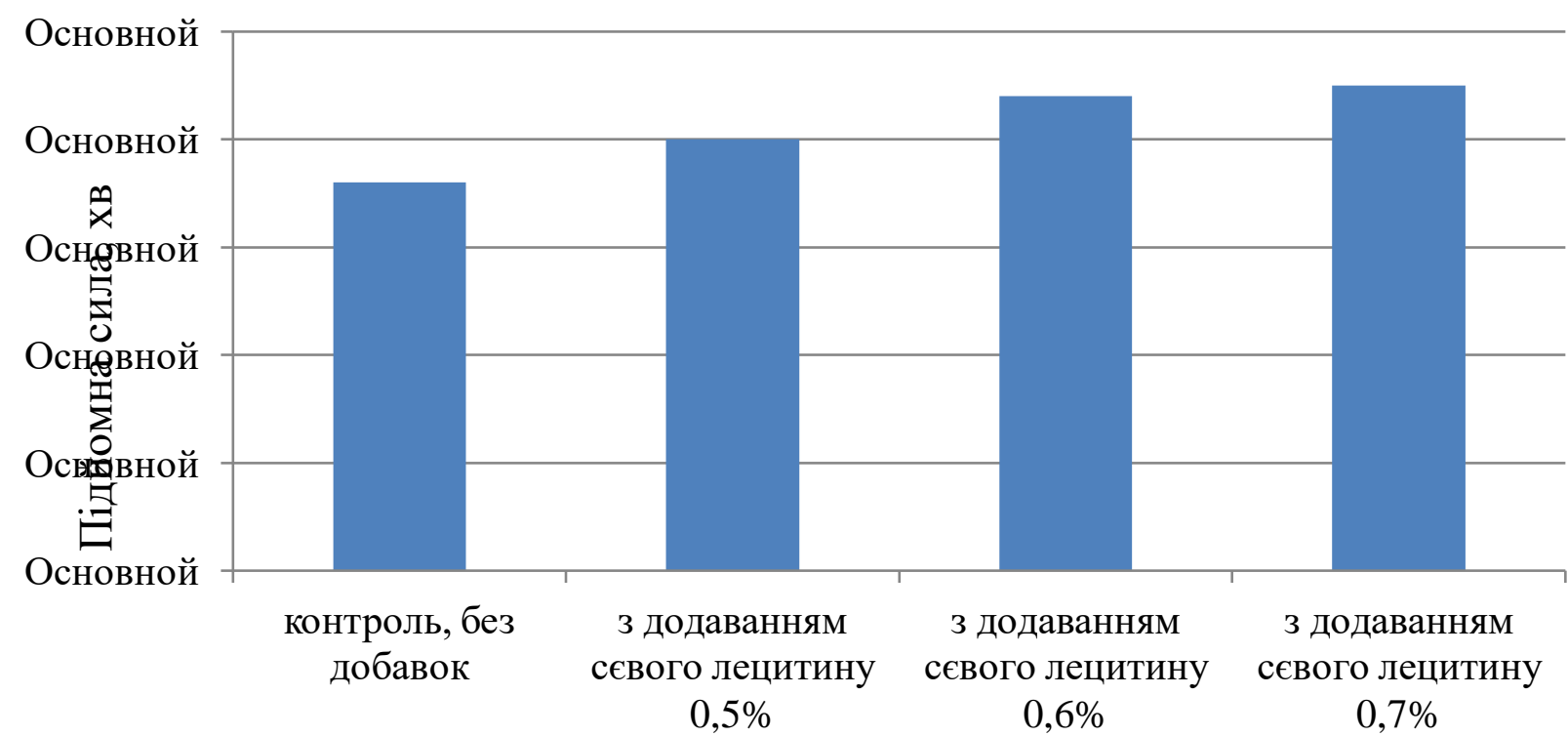

\section{Рис. 2. Характеристика підйомної сили в досліджуваних зразках}

3 рис. 2 видно, що за рахунок додавання соєвого лецитину до гірчичного хлібу підйомна сила збільшується. За усі концентрацій відзначається невелика різниця у значеннях.

Тому, за результатами проведених досліджень для удосконалення рецептури та визначення показників якості гірчичного хлібу обрано дозування соєвого лецетину у кількості $0,6 \%$. Рецептуру гірчичного хліба 3 додаванням соєвого лецитину наведено у таблиці 2.

Технологічний процес виготовлення гірчичного хліба із додаванням соєвого лецитину включає в себе такі операції: підготовка сировини i напівфабрикатів до виробництва; дозування сировини; приготування опари; приготування тіста; оброблення тіста; випікання тістових заготовок; охолодження; фасування, пакування, реалізація.

Смак і аромат є показниками якості, від яких залежить засвоєння їжі. Смак і аромат хлібобулочних виробів формуються під час тістоприготування $\mathrm{i}$ випікання тістових заготовок і залежать від складових рецептури, вмісту продуктів, які утворюються при дозріванні тіста, але вирішальну роль у їх формуванні відіграють продукти взаємодії цукрів, інших карбонільних сполук 3 амінокислотами і білками під час випікання. 
Таблиця 2

\section{Рецептура гірчичного хліба з додаванням сосвого лецитину у} кількості 0,6 \%, за фазами, кг на 100 кг борошна

\begin{tabular}{|l|c|c|c|c|}
\hline \multicolumn{1}{|c|}{$\begin{array}{c}\text { Сировина } \\
\text { напівфабрикатів }\end{array}$} & Маса, кг & В опару & В тісто & На оброблення \\
\hline $\begin{array}{l}\text { Борошно пшеничне } \\
\text { вищого гатунку }\end{array}$ & 100 & 60 & 39 & 1,0 \\
\hline Дріжджова суспензія & 8,0 & 2,0 & - & - \\
\hline Сольовий розчин & 5,77 & - & 5,77 & - \\
\hline Лецитин соєвий & 0,6 & - & 0,6 & - \\
\hline Цукор & 6,0 & - & 6,0 & - \\
\hline Олія гірчична & 6,0 & - & 6,0 & - \\
\hline Вода & 52,8 & & & \\
\hline Опара & - & - & 62,0 & - \\
\hline Разом & 179,17 & 62,0 & 117,17 & 1,0 \\
\hline
\end{tabular}

На рис. 3. представлено зовнішній вигляд свіжевиготовлених зразків хліба гірчичного з додаванням соєвого лецитину та без.

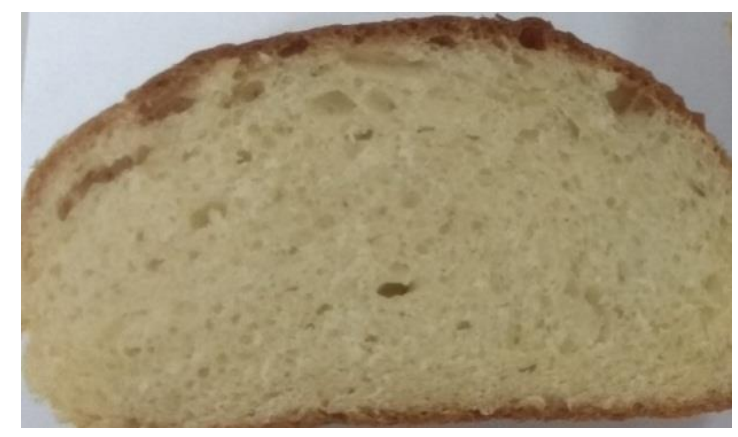

a

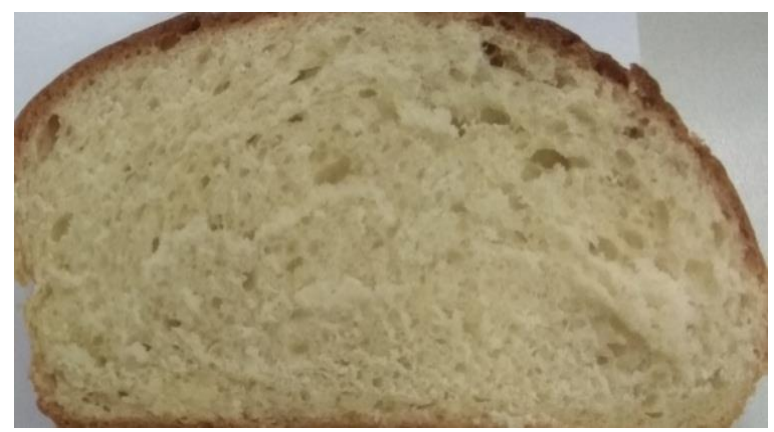

б

Рис. 3. Зовнішній вигляд свіжевиготовлених зразків хліба гірчичного: a - контроль, без добавок; б - $з$ додаванням сосвого лецитину

3 рис. 3 видно, що зразок гірчичного хліба 3 додаванням соєвого лецитину хараткеризується більш пористою структурою, що надає хлібу більш пухкої консистенції та покращує розжовуваність.

Досліджено органолептичні властивості обох зразків (табл. 3.).

3 табл. 3 видно, що зразок гірчичного хліба з додаванням соєвого лецитину характеризується більш гладенькою поверхнею, без тріщин та соковитою м’якушкою, що добре розжовується порівняно із контрольним зразком. 
Таблиця 3

\section{Органолептичні показники якості досліджуваних зразків}

\begin{tabular}{|c|c|c|}
\hline $\begin{array}{c}\text { Органолептичні } \\
\text { показники }\end{array}$ & Контроль, без добавок & 3 додаванням соєвого лецитину \\
\hline Зовнішній вигляд & $\begin{array}{c}\text { Хліб із ледве опуклою } \\
\text { верхньою скоринкою, колір } \\
\text { скоринки золотистий. } \\
\text { Поверхня гладенька, одиничні } \\
\text { пухирці, помітні тріщини }\end{array}$ & $\begin{array}{c}\text { Хліб із помітно опуклою верхньою } \\
\text { скоринкою, колір скоринки } \\
\text { золотистий. Поверхня бездоганно } \\
\text { гладенька, без пухирців, глянцева }\end{array}$ \\
\hline Стан м’якушки & $\begin{array}{c}\text { М'якушка світла,пори дрібні } \\
\text { та середні, розподілені досить } \\
\text { рівномірно }\end{array}$ & $\begin{array}{c}\text { М'якушка світла, пори дрібні та } \\
\text { середні, розподілені досить } \\
\text { рівномірно }\end{array}$ \\
\hline $\begin{array}{l}\text { Смак та аромат } \\
\text { хліба }\end{array}$ & $\begin{array}{c}\text { Інтенсивно виражений, } \\
\text { характерний хлібний }\end{array}$ & $\begin{array}{c}\text { Інтенсивно виражений, властивий } \\
\text { для хліба }\end{array}$ \\
\hline $\begin{array}{l}\text { Розжовуваність } \\
\text { м’якушки }\end{array}$ & $\begin{array}{c}\text { Досить ніжна, ледь сухувата, } \\
\text { добре розжовується }\end{array}$ & Дуже ніжна, добре розжовується \\
\hline
\end{tabular}

Проведено дослідження фізико-хімічних показників гірчичного хліба у процесі зберігання. Хліб зберігався в температурному діапазоні $20 \ldots 25^{\circ} \mathrm{C}$ та відносній вологості повітря не вище 75\%. Визначено вологість м'якушки зразків гірчичного хліба $з$ додаванням соєвого лецитину та без продовж зберігання (рис. 4).

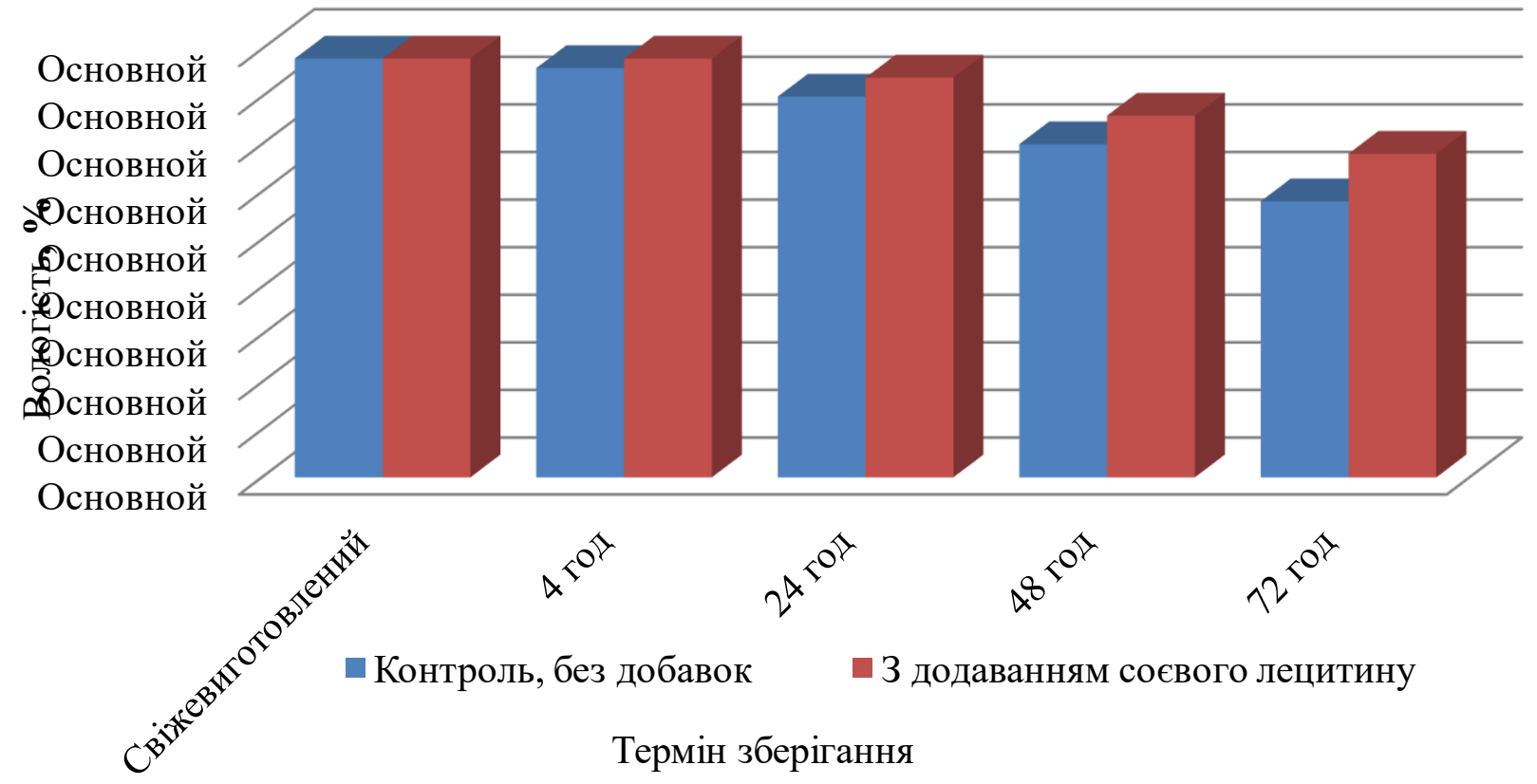

Рис. 4. Зміна вологості зразків хліба гірчичного без добавок та $з$ додаванням сосвого лецитину впродовж зберігання 
3 рис. 4 видно, що в зразку гірчичного хліба з додаванням соєвого лецитину впродовж зберігання волога утримується набагато краще. Так на 72 годину зберігання вміст вологи в гірчичному хлібі 3 додаванням соєвого лецитину вищий на 5\% у порівняні з контролем. Це доводить ефективність використання соєвого лецитину з метою збереження свіжості хліба.

Проведено визначення кислотності та пористості досліджуваних зразків впродовж зберігання (табл.4.)

Таблиця 4

Фізико-хімічні показники гірчичного хліба з різним дозуванням сосвого лецитину

\begin{tabular}{|l|c|c|c|c|c|}
\hline \multirow{2}{*}{ Показники } & \multirow{2}{*}{$\begin{array}{c}\text { Згідно } \\
\text { ДСТУ }\end{array}$} & \multicolumn{2}{|c|}{ Контроль, без добавок } & \multicolumn{2}{|c|}{ 3 додаванням соєвого } \\
$7517: 2014$ & \begin{tabular}{c} 
лецетину \\
\cline { 3 - 6 }
\end{tabular} & Свіжевигот & $\begin{array}{c}\text { Після } \\
\text { овлерігання } \\
72 \text { год }\end{array}$ & $\begin{array}{c}\text { Свіжевигото } \\
\text { влений }\end{array}$ & $\begin{array}{c}\text { Після } \\
\text { зберігання } \\
72 \text { год }\end{array}$ \\
\hline $\begin{array}{l}\text { Кислотність } \\
\text { м'якушки, град, } \\
\text { не більше }\end{array}$ & 3,0 & 2,4 & 2,8 & 2,5 & 2,9 \\
\hline $\begin{array}{l}\text { Пористість } \\
\text { м'якушки, \%, не } \\
\text { менше }\end{array}$ & 72,0 & 70,8 & 70,0 & 73,77 & 71,8 \\
\hline
\end{tabular}

3 табл. 4 спостерігається незначна зміна кислотності впродовж зберігання. Але показник пористості $\epsilon$ вищим як у свіжевиготовленого зразка так і після зберігання впродовж 72 год.

Про ступінь свіжості можна судити по зміні гідрофільних властивостей колоїдів м'якушки впродовж зберігання хлібобулочних виробів.

Висновки та перспективи подальших досліджень. Удосконалено рецептуру хліба гірчичного 3 додаванням соєвого лецитину та підібрано оптимальне дозування добавки. За результатами органолептичних показників та досліджень підйомної сили для розроблення рецептури та технологічної схеми виробництва для визначення показників якості гірчичного хлібу обрано дозування соєвого лецетину у кількості $0,6 \%$.

Досліджено органолептичні та фізико-хімічні показники хліба гірчичного 3 додаванням соєвого лецитину та надано порівняльну характеристику 3 контрольним зразком 
В подальшому доцільним є дослідження зміни показників свіжості хліба впродовж зберігання. Про ступінь свіжості можна судити по зміні гідрофільних властивостей колоїдів м'якушки впродовж зберігання хлібобулочних виробів.

В процесі зберігання змінюються структурно-механічні властивості м'якушки, стінки пор втрачають свою міцність, що супроводжується збільшенням кришкуватості м'якушки. Зменшення гідрофільних властивостей м'якушки впливає на зниження ії здатності до набухання і поглинання води, а також здатність інших речовин м'якушки переходити у водний розчин.

Тому в перспективі доцільним є дослідження показників крихкуватості та набрякання впродовж зберігання зразків хлібу з соєвим лецитином та без.

\section{Список використаних джерел}

1. Пащенко, Л.П. Процессы, протекающие в хлебе при черствении Технология хлебопекарного производства: учебник / Л.П. Пащенко, И.М. Жаркова. - Спб.: Издательство «Лань», 2014. - 672 с.

2. Шуб, І. Цукровмісний сироп подовжує свіжість пшеничного хліба з борошна першого сорту / І. Шуб, М. Логінова, О. Аношина // Журнал Хлібопекарська і кондитерська промисловість України № 9. 2013 - с. 36.

3. Шаран, Л. Ю. Дослідження впливу морських водоростей на показники якості та процес черствіння хлібобулочних виробів / Л. Ю. Щаран // Журнал зберігання і переробки зерна № 12.2010 - с. 61-62

4. Письменний, В. В. Хлеб с овощными порошками / В. В. Письменний// ХлебопечениеРоссии № 4. 2006. - с. 24

5. Хліб із пшеничного борошна. Технічні умови : ДСТУ 7517:2014. - [Чинний від 2015-02-01]. - К. :Держспоживстандарт України, 2015. - 14 с. - (Національний стандарт України).

6. Вироби хлібобулочні. Методи визначання фізико-хімічних показників: ДСТУ 7045:2009. - [Чинний від 2010-01-01]. - К.: Держстандарт України, 2010. - 40 с. (Національний стандарт України)

7. Дробот B.I. Лабораторний практикум 3 технології хлібопекарського та макаронного виробництв / В.І. Дробот, Л.Ю. Арсеньєва, О.А. Білик, В.Ф. Доценко та ін. Навчальний посібник. - К.: Центр навчальної літератури, 2006. - 341 с.

8. Янчик, М. Обгрунтування рецептури гірчичного хліба 3 додаванням соєвого лецитину / М.В. Янчик, В.В. Кійко // Міжнародна науково-практична конференція для молодих учених та студентів «Якість та безпека товарів», 3 квітня 2020 р. - Л.: ЛНТУ, 2020 p. -180 c., C. 82.

\section{References}

1. Pashhenko, L.P. Processu, protekayushhy'e v xlebe pry` cherstveny'y' Texnology`ya xlebopekarnogo proy`zvodstva: uchebny`k / L.P. Pashhenko, Y'.M. Zharkova. Spb.: Y`zdatel'stvo «Lan`», 2014. - $672 \mathrm{~s}$. 
2. Shub, I. Czukrovmisny`j sy`rop podovzhuye svizhist` psheny`chnogo xliba $\mathrm{z}$ boroshna pershogo sortu / I. Shub, M. Loginova, O. Anoshy`na // Zhurnal Xlibopekars`ka i kondy`ters`ka promy`slovist` Ukrayiny`\# 9.2013 - s. 36.

3. Sharan, L. Yu. Doslidzhennya vply`vu mors`ky`x vodorostej na pokazny`ky` yakosti ta proces cherstvinnya xlibobulochny`x vy`robiv / L. Yu. Shharan // Zhurnal zberigannya i pererobky`zerna \# 12. 2010 - s. 61-62

4. Py`s menny`j, V. V. Xleb s ovoshhnыmy` poroshkamy` / V. V. Py`s`menny`j// Xlebopecheny`eRossy`y`\# 4. 2006. - s. 24

5. Xlib iz psheny`chnogo boroshna. Texnichni umovy`: DSTU 7517:2014. [Chy`nny`j vid 2015-02-01]. - K. :Derzhspozhy`vstandart Ukrayiny`, 2015. - 14 s. (Nacional’ny`j standart Ukrayiny`).

6. Vy`roby` xlibobulochni. Metody`vy`znachannya fizy`ko-ximichny`x pokazny`kiv: DSTU 7045:2009. - [Chy`nny`j vid 2010-01-01]. - K.: Derzhstandart Ukrayiny`, 2010. - 40 s. (Nacional`ny`j standart Ukrayiny`)

7. Drobot V.I. Laboratorny`j prakty`kum z texnologiyi xlibopekars`kogo ta makaronnogo vy`robny`cztv / V.I. Drobot, L.Yu. Arsen`yeva, O.A. Bily`k, V.F. Docenko ta in. Navchal`ny`j posibny`k. - K.: Centr navchal noyi literatury`, 2006. - 341 s.

8. Yanchy`k, M. Obg`runtuvannya receptury` girchy`chnogo xliba z dodavannyam soyevogo lecy`ty`nu / M.V. Yanchy`k, V.V. Kijko // Mizhnarodna naukovo-prakty`chna konferenciya dlya molody'x ucheny'x ta studentiv «Yakist' ta bezpeka tovariv», 3 kvitnya 2020 r. - L.: LNTU, 2020 r.- 180 s., S. 82.

Цель. Усовершенствование рецептуры хлеба горчичного с использованием соевого лециитина и определение влияния выбранной добавки на показатели качества готового продукта в течение хранения

Методика. Для исследования показателей качества хлеба горчичного использовали общепринятые методики определения органолептических показателей, влажности, кислотности, пористости, подъемной силь

Результаты. Усовершенствована рецептуру хлеба горчичного с добавлением соевого лечитина, обоснованно технологическую схему его производства и подобрано оптимальную дозировку добавки. По результатам органолептических исследований $и$ подъемной силь избрано дозирования соевого лецитина в количестве 0,6\%.

Исследовано органолептические и физико-химические показатели хлеба горчичного с добавлением соевого лецитина и без его использования. Выявлено, что образец горчичного хлеба с добавлением соевого леичитина характеризуется более гладкой поверхностью, без трещин и мякишем с равномерно распределенными порами, хорошо разжевывается по сравнению с контрольным образцом. Доказано, что в образие горчичного хлеба с добавлением соевого лецитина в течение хранения влага удерживается гораздо лучше, наблюдается незначительное изменение кислотности в течение хранения, а показатель пористости выше как в свижевиготовленого образца так и после хранения.

Научная новизна. Впервые усовершенствована рецептуру горчичного хлеба за счет, добавления соевого лецитина и исследованы его показатели качества.

Практическая значимисть. Результаты, которые были получены в ходе исследований, можно внедрить на хлебопекарных предприятиях Украины независимо от форм собственности и подчинения

Ключевые слова: горчичный хлеб, соевый лецитин, показатели качества

Purpose. Improvement of the mustard bread recipe using soy lecithin and determination of the effect of the selected additive on the quality indicators of the finished product during storage. 
Methods. To study the quality indicators of mustard bread, we used the generally accepted methods for determining organoleptic indicators, moisture, acidity, porosity and lifting force.

Results. The formulation of mustard bread with the addition of soy lecithin has been improved, the technological scheme of its production has been substantiated, and the optimal dosage of the additive has been selected. According to the results of organoleptic studies and lifting force, the dosage of soy lecithin in the amount of $0.6 \%$ was selected.The organoleptic and physicochemical characteristics of mustard bread with the addition of soy lecithin and without its use have been investigated. It was found that a sample of mustard bread with the addition of soy lecithin is characterized by a smoother surface, without cracks and crumb with evenly distributed pores, well-chew compared to the control sample. It has been proven that in a sample of mustard bread with the addition of soy lecithin during storage, moisture is retained much better, a slight change in acidity is observed during storage, and the porosity index is higher both in the baked sample and after storage.

Scientific novelty. For the first time, the recipe of mustard bread was improved by adding soy lecithin and its quality indicators were studied.

Practical significance. The results that were obtained in the course of research can be introduced at bakery enterprises of Ukraine, regardless of the form of ownership and subordination.

Key words: mustard bread, soy lecithin, quality indicators.

Стаття рекомендована до публікаиіi доктором сільсько-господарських наук, професором кафедри експертизи харчових продуктів НУХТ Гуменюк Г.Д. Стаття надійшла в редакиію 15.02.2020 р. 